\title{
Analysis of SERVQUAL Application to Service Quality Measurement and Its Impact on Loyalty in Ghanaian Private Universities
}

\author{
Stephen Banahene ${ }^{1}$, Eric Ahudey ${ }^{1} \&$ Abigail Asamoah ${ }^{1}$ \\ ${ }^{1}$ School of Business, Christian Service University College, Ghana \\ Correspondence: Stephen Banahene, Lecturer, School of Business, Christian Service University College, Ghana.
}

Received: May 22, 2017

Accepted: June 5, 2017

Online Published: July 17, 2017

doi:10.5430/jms.v8n4p18

URL: https://doi.org/10.5430/jms.v8n4p18

\begin{abstract}
The purpose of this research is to use an adapted SERVQUAL method to measure service quality in Ghanaian Private Universities. The study use graphical technique for data presentation.

The methodological approach follows the traditional SERVQUAL method of service quality perception and expectation as well as the difference scores determination. This approach is intended to improve SERVQUAL method analysis to achieve quality decision making based on graphical view of different relationships among the concepts used in the method. The study is on 321 students' perception and expectations of five different Private Universities in Ghana.

The study finds that students' perception on Private Universities' performance predict their loyalty better than the expectations. Managerial action can be better taken on service quality variables when the difference scores are used as percentage on perception. However, different service quality measurement methods such as SERVPERF and HEdPERF should be used and compared the results with this modified SERVQUAL method in Ghanaian Private Universities.

This research finding has the strength to equip marketing professionals and researchers to increase SERVQUAL method adoption among different academic institutions.

The value in this study is found in highlighting the importance of difference scores and the graphical demonstration of relationships among service quality perception and expectation as well as loyalty constructs in Ghanaian Private Universities.
\end{abstract}

Keywords: SERVQUAL, SERVPERF, HEdPERF, higher educaton and service quality measurement

\section{Introduction}

Tertiary education is becoming commercially oriented due to economic and social forces emanating from key stakeholders of higher education. In Ghana, government is the principal funding agent to public universities but is gradually pushing for funding diversification. Private universities are also mainly funded by students' fees and this makes it important to provide quality service to students. Again, universities must not only be interest in the academic knowledge and skill capabilities developed by their students (Ginsberg, 1991; Lawson, 1992), they are as well needed to be concerned with how students feel about the educational experience (Bemowski, 1991) to promote loyalty even after graduation. What is significant to note is that, some students are managers in service organisations, successful entrepreneurs, experienced in service quality management, religious leaders, opinion leaders and formers, and have appreciable economic wealth. These attributes place some students in a unique position to expect and demand service quality that are delivered to them. This perspective makes service quality delivered to students to focus on academic standards, accreditation requirements, and students' perception and expectation indicators.

The Ghanaian Private University education system is facing a number of challenges and opportunities today. The dynamic business environment, strategic behaviour of mentor institutions, changing nature of socio-demographic features and state institutions mandated to regulate tertiary education (thus, National Accreditation Board and National Council for Tertiary Education) and their framework for operation are affecting Private University's management strategies. As part of National Accreditation Board's requirement for institutional and programme re-accreditation, Private universities are required to provide students' satisfaction survey report. Most universities 
use students' satisfaction survey to assess faculty and non-faculty members for promotion. And more importantly, providing quality service is the most powerful way to shape marketing strategy.

Service quality has grown to be a strategic issue for marketing professionals and researchers alike. The pressures that are pushing Private Universities to render quality service make the measurement of it very important. Service quality measurement is essential for strategic planning (Hammasi et al, 1994) and has become the key driver to assess Private University's marketing and financial performance (Buttle, 1996). Notwithstanding, the difficulties in the measurement of service quality for marketing strategy has been challenging given the nature of service quality construct. Though many researchers have worked on service quality, there are still unresolved issues that call for attention. One of such controversial issues has to do with service quality measurement and how the process and outcome of it can be applied to marketing strategies.

The use of the SERVQUAL method is widely known and is abounding in western literature since 1980s (Parasuraman et al, 1988; Cronin and Taylor, 1992; Buttle, 1996; and Dabholkar et al, 2000). From the late 2000, the original idea on SERVQUAL method as developed by Parasuraman et al (1988) has been extensively discussed, developed and criticized in a number of publications in marketing and management textbooks, research papers and case studies (Sureshchandar et al., 2001; Baumann et al., 2007; and Chingang Nde Daniel and Lukong Paul Berinyuy, 2010). The SERVQUAL method relies mainly on the difference in scores between perception and expectation variables to determine satisfaction with five main dimensions: tangibility, reliability, responsiveness, assurance, and empathy (Parasuraman, Zeithaml and Berry, 1988).

Further to the criticisms arising from the difficulty to use difference scores (Teas, 1993; Cronin and Taylor, 1992, 1994; and Oliver, 1980), Predvoditeleva and Balaeva, 2005) Cronin and Taylor (1994) have proposed the use of perceived aspect of service delivered to customers. These authors referred to this measurement scale as SERVPERF. In the SERVPERF method, service quality is measured solely on performance to suggest that performance-based measure explains the variance in the overall measure of service quality better (Oliver, 1989; Bolton and Drew, 1991; Cronin and Taylor, 1992; Boulding et al, 1993; Quester et al., 1995). What these researchers found has indicated SERVPERF superiority in terms of reliability in estimation, convergent and discriminant validity, explanation to variances, and bias in reporting research output. Abdullah (2005) has also developed HEdPERF, a more comprehensive performance-base measure to service quality in higher education sector only.

It must be appreciated that, service quality is an elusive concept and difficulty continues to emerge on appropriateness of measurement scales. After Lewis and Booms (1983) define service quality to be how well a given service level delivered to customers meets their expectations, a good number of researchers have agreed that service quality is an attitude of the total judgment about service superiority. However, it is still difficult to describe the nature of attitude in service quality. In an attempt to explain the nature of service quality as an attitude, some researchers have concluded it to be the difference between perceptions and expectations (Parasuraman et al, 1988), others see it to be a comparison of performance and ideal standards (Teas, 1993), and finally from the perception of performance only (Cronin and Taylor, 1992). The debate is still between performance-base measure and difference scores-base measure. This makes it imperative to acknowledge that both performance-base and difference scores-base approach to the measurement of service quality has some merits. Therefore, to optimize service quality measurements available, researchers and marketing professionals should aspire to use measurement scales that draw on performance-base and difference scores-base methods to improve on the meaning of data as service quality involves processes and events. An attempt to ignore one part may not help the discourse to improve service quality construct. Oliver's (1980) disconfirmation model supports that, customers' satisfaction is measured using their expectation and perception to determine their positive, negative or zero disconfirmations.

As regards the measurement scales, available literature gives a good number of service quality evaluative scales which are rooted from conceptual models (Parasuraman et al, 1988) and empirical analysis and experimentation in service sectors (Cronin and Taylor, 1992; Franceschini and Rossetto, 1997). The most measures used in service quality evaluation have the feature of quantitative and multi-attribute. In these quantitative and multi-attribute methods, SERVQUAL method has been noted to be prominent. The significance of service quality measurement does not only lies in the strongest measure in quantitative terms, but also how the measurement scale can unearth practical issues for marketing strategy design and implementation. The performance-base and difference scores-base measurements have their respective strengths and weaknesses. It then becomes useful to draw lessons from both perspectives to maximize effort to achieve powerful service quality delivery.

Likewise et al (1993) have posited that, service quality is only influenced by perception. Quester et al (1995) and Cronin and Taylor (1988) have empirical test to support the superiority of SERVPERF method. Teas (1993) has 
expressed the conceptual and operational difficulties in the use of SERVQUAL method, particularly the use of the expectation variables. Good as their findings are to the measurement of service quality, the expectation variables has some values. Perhaps, the value can be better appreciated when designing marketing strategy for implementation. For example, a lower satisfaction score may be as a result of over expectation of customers and this calls for expectation management more than performance actions. In addition, the expectation can also form the basis from which service quality measurement can be compared to ascertain progress of service quality achievement by organisations. This makes it not too surprising that SERVQUAL has become institutionalized and utilized over the time (Carman, 1990; Dabholkar et al, 1996, 2000; Kwon and Lee, 1994; Crompton and Mackay, 1989; Saleh and Ryan, 1991; McElwee and Redman, 1993; Fadeeva, 2012; and Galeeva, 2016). Based on available literature, the authors' review indicates the following needs that are associated with the SERVQUAL method:

(i) The quality gap provides less useful information as the difference scores can be misleading (Babakus and Boller, 1992 cited by Galeeva, 2016). However, the difference scores can be analysed graphically to overcome the challenge of less meaning to such quality gap scores.

(ii) Customer satisfaction and perceived service quality can provide better meaning when ratios are used (Oliver, 1980). In addition, graphical presentations can also improve the data meaning.

(iii) Graphical presentations provides precise data meaning than statistics (Tufte, 2001), but Parasuraman et al $(1985,1988)$ did not give graphical view of the service quality data.

In most literatures, loyalty is investigated as a component of one general dimension or two (attitudinal and behavioural) dimensions and only few authors analyse loyalty components in four dimensions (Oliver, 1997; Sivadas, Baker-Prewitt, 2000; Olsen, 2002; Harris, Goode, 2004; Han, et a. 2008). The approach to study loyalty in one or two dimensions limits how behavioural patterns and psychological perspectives of customers can be understood. To extend the originality of this study, four loyalty dimensions (cognitive, affective, conative, action) are used to predict service quality outcome in terms of students' cognitive, affective, conative and action but not of other motivations. The use of the four dimensions of loyalty in this study is intended to improve the traditional applications of SERVQUAL method to marketing effectiveness.

This study has the objective to explore SERVQUAL method by using graphical presentations and regression analysis to track service quality analysis process to achieve service quality strategy implementations. The information on perception and expectations in service quality measurement can be explored further to enhance marketing decision. Organisations are not only to manage what they do in service quality, but also to manage service quality expectations from customers. It must be admitted that, some service quality expectations are unrealistic and unattainable, whiles others are far below what customers require to know in a particular service setting. The authors believe that SERVQUAL approach provides information on customers' perception, expectation and satisfaction that can be considered in their own rights for strategic analysis and implementation. The second objective is to examine the relationship between SERVQUAL method and loyalty to determine the predictive power of perception and expectation to loyalty for marketing strategy.

\section{Literature Review}

What most authors say about service quality are the feelings about the process of evaluating what is experienced from a focal organisation (Armstrong \& Kotler, 1996). Conventionally, quality of service is treated to be the difference between what customers expect and their perceptions on a given service variables (Gronroos, 2001; Parasuraman, Zeithaml, and Berry, 1988). To some authors, the quality of service is the extent to which a service meets customers' needs (Lewis and Mitchell, 1990; Dotchin and Oakland, 1994). Another group of authors also consider service quality as the customers' impression of the relative inferiority or superiority of the service (Zeithaml, Berry, and Parasuraman, 1990). Asubonteng, McCleary, and Swan (1996) have identified different service quality dimensions in different industries.

A team of faculty members in the Nordic Business School worked to provide methodological foundations for service quality research and identified two service quality dimensions namely technical and functional. The technical dimension looks at the "what" and the functional considers the "how" of service delivery. Crosby (1979) has noted that, some United State of America researchers have also investigated service quality and its relationship to costs, defect reduction and profitability. Sasser et al (1979) had discussed dimensions of service performance namely materials, facilities and personnel and argued that service quality involves outcomes and delivery processes. The research findings of the Nordic and United State of America researchers has provided the conceptual foundation for 
SRVQUAL method (Parasuraman et al, 1985, 1988). SERVQUAL method is presently used as the most preferred service quality measurement method (Buttle, 1996; Kang and James, 2004).

\subsection{SERVQUAL Model}

Researchers have used SERVQUAL method to identify the important components of service quality for adaptation in tertiary education sector (McElwee and Redman, 1993). In recent years, the use of SERVQUAL method in education have extended to national, international and cross-cultural context including India (Chatterjee et al, 2009), Spain (Gallifa and Batalle, 2010), Germany (Gruber et al, 2010), Australia (Rodrigues et al., 2011; Sultan and Wong, 2012) and Pakistan (Ilyas et al., 2013). In the works of Parasuraman et al, (1988), SERVQUAL uses the difference between customers' expectations and perceptions to represent the quality gap. The score difference is the ratings respondents give on perception and expectation on the twenty two service criteria items in an organized five dimensions namely tangibility, reliability, responsiveness, empathy and assurance. Abdullah (2005) has also developed HEdPERF instrument which has been applauded to be an advanced educational service quality measurement scale. However, the HEdPERF method has its foundation from SERVPERF model which has its root from performance-base approach (Cronin and Taylor, 1992, 1994).

SERVQUAL method has been used by different authors and in varied service sectors. In Russia, Novatorov (2000, 2001 and 2012) successfully applied SERVQUAL to education, medical services, cultural and leisure services, and non-profit sector. Novatorov and Novitskaya (2012), Avkiran (1994) and Lee et al (2000) have also used SERVQUAL in the banking sector. Milyaeva $(2004,2005)$ has used SERVQUAL method to measure satisfaction levels of internal customers and external stakeholders such as alumni and employers. Shemyakin (2008) has implemented SERVQUAL in identifying budget priorities using six dimensions that have their individual quality and important scores. In the works of Ponomoreva and Supryagina (2005), SERVQUAL method has been noted to be the foundation to the development of service quality measurements. In other parts of the world, Ojo (2010) used SERVQUAL to do research in the telecommunication sector in Nigeria. Keheng et al (2010) also used this measurement scale in the banking sector in Malaysia. Saghier and Demyana (2013) used SERVQUAL in the banking sector in Egypt. In Ghana Peprah (2014) and Essiam (2013) have used SERVQUAL in measuring service quality in health care. Cudjoe et al (2015) and Sackey et al (2012) have also used SERVQUAL as a measurement tool in the banking industry. In the transport sector, Ojo et al (2014) used SERVQUAL measurement. This shows that SERVQUAL is in continuous use because of its user friendly and provision of comprehensive information from customers' perspective for service quality management.

\subsection{Customer Loyalty}

On the definition of loyalty, there are number of different opinions. Oliver (1997) has emphasised that, customer loyalty is about deep commitment to the purchase of a product in a consistent manner or sticking to the same brand. This means that, loyal customers do not switch to other brands under the influence of change in market and other economic conditions. By this way, customer loyalty can be considered as an attitude and behaviour construct. In the works of Gronholdt et al (2000) as cited by Du and Tang (2014), customer loyalty is made up of four factors namely repurchase intention, price tolerance, referrals, and cross-buying intentions. Yao Dan (2011) has also noted that, loyalty covers customer's behaviour and emotions. This study is interested in loyalty because it provides theoretical and managerial implications for marketing professionals and researchers (Aaker, 1992; Reichheld, 1996). In the service sector, most researchers have emphasised the importance of loyalty which leads to lower marketing cost (Aaker, 1991), promotes brand extension and stretching, and increase market shares (Buzzel et al, 1975; Buzzell and Gale, 1987). Loyalty studies have also indicated positive word of mouth relationship and reduction of customers' resistance (Dick and Basu, 1994).

\subsection{Relationship between Service Quality and Customer Loyalty}

As regards the relationship between service quality as measured by SERVQUAL method and customer loyalty, many researchers have come with different findings. Parasuraman et al $(1985 ; 1988)$ have found that, service quality and customer's behavioural intention is close and that customer's action to buy a product is influenced by the level of service quality provided by service organisations. They also found that, service quality also affects customer's willingness to refer organisation's services to others. Chunxiao et al (2001) empirical studies have found significant direct effect of service quality on customer behavioural intentions. In another study by Xiaoyun and Chunxiao (2003), they found service quality's direct impact on customer's cognition and emotional loyalty. After an investigation in training industry, Hongcui (2008) found that SERVQUAL dimensions of tangibility, responsiveness and empathy have direct effect on customer loyalty. All these findings indicate that, service quality has positive relationship to customers' loyalty and purchase behaviours. 


\section{Research Methodology}

\subsection{Research Objectives}

On the basis of SERVQUAL authors and recommendations of other researchers who have used SERVQUAL measurement scale, this research uses graphical techniques and regression analysis to explore performance-base, difference score-base, and satisfaction data as given by the respondents of this study. In specific terms, the original SERVQUAL method items were adapted for data acquisition but use graphical approach for the data analysis and presentation of results with the aim to enhance meaning of the results to researchers, marketing professionals and other service operational managers.

\subsection{Research Design}

The research data were collected by the use of structured questionnaire made up of three sections. The sections A and B contain twenty two (22) items each on perception and expectation respectively and covered the five dimensions of SERVQUAL method (Parasuraman et al, 1988). The section C had thirteen (13) modified items on loyalty to suit the study context but covered the four (4) dimensions as developed by Bobalca et al (2012). The items in the three sections were presented as statements on the questionnaire with rating scales ranging from 1 (strongly disagree for SERVQUAL and strongly disloyal for loyalty) to 7 (strongly agree for SERVQUAL and strongly loyal for loyalty). The drafted questionnaire were put to test with 25 students and were requested to give their opinion on the state of the questions in the area of clarity, omissions and errors. The feedbacks received were on the number of questions involved which translates to more time needed for completion, and clarity of some items. Number of questions could not be reduced due to the research scope but action was taken on the clarity of the questions. Subsequently, the revised questions were sent to two faculty members whose specialties are in service marketing and one Registrar of a Private University. The two faculty members and the Registrar accepted the questions as they conform to SERVQUAL method and the Loyalty measurement scale.

The questions were administered to students from five Private Universities (three faith-based and two secular-based) located in Kumasi, Ghana. The data was collected using personal contact approach with students on campus as in line with the recommendations by Sureshchandar et al (2002) that personal contact provides detail engagement to survey.

In all, 380 questionnaires were sent to the five Private Universities and 352 were valid out of the 361 returned questions. The number of usable sample size was $92.63 \%$. The usable sample size of 352 for a population size of nearly 5000 active students in the Private Universities that were involved in the study was in line with the generalised scientific guideline for sample size decisions as recommended by Krejcie and Morgan (1970). As regards method of analysis, the original SERVQUAL method of analysis was implemented (Parasuraman et al, 1988) for each criterion and quality gap was calculated as follows:

$$
\text { Satisfaction }(\mathrm{S})=\text { Perception }(\mathrm{P})-\text { Expectation }(\mathrm{E})
$$

Following Novatorov (2001), the results were presented in a graph format with the quality gap, here described as satisfaction as an indicator of the difference between perception and expectation. In addition, the authors presented graphical view of loyalty as a response variable to perception, expectation and satisfaction to improve marketing decisions on service quality management.

\subsection{Dimensionality of SERVQUAL Method}

The confirmatory factor analysis capabilities were determined on all the SERVQUAL variable (both perception and expectation) items as were found by Parasuraman et al (1988). Similar analysis was done to the Loyalty dimensions. The same factor structures were identified for the SERVQUAL and Loyalty. This shows that both measurement scales conform to the original feature of the methods.

\section{Results and Discussions}

The first step was to enter the data into SPSS 17.0 and checked for incorrect entries and missing data. A series of exploratory factor analysis (EFA) were performed to purify the scales, evaluate their internal consistency, and assess their discriminant validity. A test of reliability was conducted to measure the reliability of each measurement item to measure their said constructs. Cronbach's alpha values for all variables were high, exceeding or were very close to 0.7 cut-off as recommended by Hair et al (2010). Based on estimated reliability coefficients, it was apparent that the adapted SERVQUAL scale was a highly reliable instrument. Tables 1 and 2 below give the reliability results. 
Table 1. Reliability results for the SERVQUAL Method

\begin{tabular}{lllll}
\hline S/N & Dimension & $\begin{array}{l}\text { Number of } \\
\text { Items }\end{array}$ & $\begin{array}{l}\text { Cronbach Alpha for } \\
\text { Perception }\end{array}$ & $\begin{array}{l}\text { Cronbach Alpha for } \\
\text { Expectation }\end{array}$ \\
\hline 1 & Tangibility & 4 & 0.793 & 0.701 \\
\hline 2 & Reliability & 5 & 0.821 & 0.694 \\
\hline 3 & Responsiveness & 4 & 0.799 & 0.753 \\
\hline 4 & Empathy & 5 & 0.858 & 0.702 \\
\hline 5 & Assurance & 4 & 0.835 & 0.690 \\
\hline
\end{tabular}

Table 2. Reliability results for the loyalty scale

\begin{tabular}{llll}
\hline S/N & Dimension & Number of Items & Cronbach Alpha \\
\hline 1 & Cognitive & 3 & 0.834 \\
\hline 2 & Affective & 5 & 0.907 \\
\hline 3 & Conative & 2 & 0.778 \\
\hline 4 & Action & 3 & 0.787 \\
\hline
\end{tabular}

The researchers employed confirmatory factor analysis (CFA) to validate the scales used in the study. In line with recommended approaches, covariance matrix was used as the input and the maximum likelihood was also used as the estimation method (Vieira, 2011; Harrington, 2009). The researchers again conducted multiple CFAs (i.e. subsets) for scales that are conceptually related. This was done in order to avoid the risk of unnecessarily deleting measures (Boso et al., 2013). Following concerns regarding research that deploys self-report instruments such as questionnaires as used in this study as a possible source of bias, it became expedient for the researchers to assess the presence of common method bias (CMB) in the study (Podsakoff et al., 2003). A method-only model was estimated by linking all the measures to a single factor. The analysis yielded poor model fit indices and therefore a conclusion was reached that $\mathrm{CMB}$ does not largely describe the data used in the study and as such there is no problem in the study.

The Kaiser-Meyer-Oklin (KMO) measure verifies the sampling adequacy. The sample size is considered to be adequate for factor analysis given that the KMO for perception was 0.935, expectation was 0.906 and Loyalty for 0.940 which are well above 0.7 (Hutchson and Sofroniou, 1999). For each factor, the item scores were added together and divided by the number of items that loaded onto that component to yield a factor score that range from 1 to 7 .

\subsection{Analysis of Perception, Expectation and Satisfaction}

The mean scores for perception, expectation and satisfaction are presented in Table 3 below.

Table 3. Mean score for perception, expectation and satisfaction

\begin{tabular}{|c|c|c|c|c|}
\hline Items & $\begin{array}{l}\text { Perception } \\
\text { (P) }\end{array}$ & $\begin{array}{l}\text { Expectation } \\
\text { (E) }\end{array}$ & $\begin{array}{l}\text { Satisfaction } \\
\text { (P-E) }\end{array}$ & $\begin{array}{l}\text { Satisfaction as \% } \\
\text { to Perception }\end{array}$ \\
\hline Modern looking equipment & 4.65 & 6.15 & -1.5 & $-32.26 \%$ \\
\hline Virtually appealing of physical facilities & 4.79 & 5.91 & -1.12 & $-23.38 \%$ \\
\hline Staff appearance & 5.58 & 6.17 & -0.59 & $-10.57 \%$ \\
\hline Cleanliness of physical environment & 5.46 & 6.35 & -0.89 & $-16.30 \%$ \\
\hline Delivery promises & 4.52 & 6.06 & -1.54 & $-34.07 \%$ \\
\hline Getting things done right the first time & 4.35 & 5.57 & -1.22 & $-28.05 \%$ \\
\hline Provision of services at promise time & 4.55 & 5.94 & -1.39 & $-30.55 \%$ \\
\hline
\end{tabular}




\begin{tabular}{lllll}
\hline Insistence of error-free records & 4.61 & 5.53 & -0.92 & $-19.96 \%$ \\
\hline Sincere interest to solve students' problems & 5.41 & 6.15 & -0.74 & $-13.68 \%$ \\
\hline Prompt services to students & 4.85 & 5.98 & -1.13 & $-23.30 \%$ \\
\hline Sincere interest to solve students' problems & 4.56 & 5.78 & -1.22 & $-26.75 \%$ \\
\hline Willingness to help students & 4.88 & 5.94 & -1.06 & $-21.72 \%$ \\
\hline Making information obtainable by students & 5.05 & 6.09 & -1.04 & $-20.59 \%$ \\
\hline Giving students individual attention & 4.38 & 5.39 & -1.01 & $-23.06 \%$ \\
\hline Giving students personal attention & 4.25 & 5.59 & -1.34 & $-31.53 \%$ \\
\hline Having students' best interest at heart & 4.72 & 5.86 & -1.14 & $-24.15 \%$ \\
\hline Understanding specific needs of students & 4.27 & 5.69 & -1.42 & $-33.26 \%$ \\
\hline Operating hours convenient to all students & 4.68 & 5.58 & -0.90 & $-19.23 \%$ \\
\hline Knowledge to answer students' questions & 4.67 & 5.83 & -1.16 & $-24.84 \%$ \\
\hline Instilling confidence behaviour in students & 4.64 & 6.02 & -1.38 & $-29.74 \%$ \\
\hline Feeling safe in dealing with Private & 4.87 & 6.15 & -1.28 & $-26.28 \%$ \\
University & & & & \\
\hline Consistently courteous with students & 5.08 & 5.76 & -0.68 & $-13.39 \%$ \\
\hline
\end{tabular}

The data in Table 3 above shows that in situations where perceived service quality performance is low satisfaction is also low and vice versa. In contrast, where expectations are high perception on service quality performance is also high but satisfaction becomes good. The regression analysis in Appendix 1 shows this information. An analysis of the satisfaction as a percentage to perception on performance shows that items like "modern looking equipment" and "understanding specific needs of students" require marketing actions to improve service quality.

The graphical view of the Satisfaction as percentage to perception is shown in Figure 1 below.

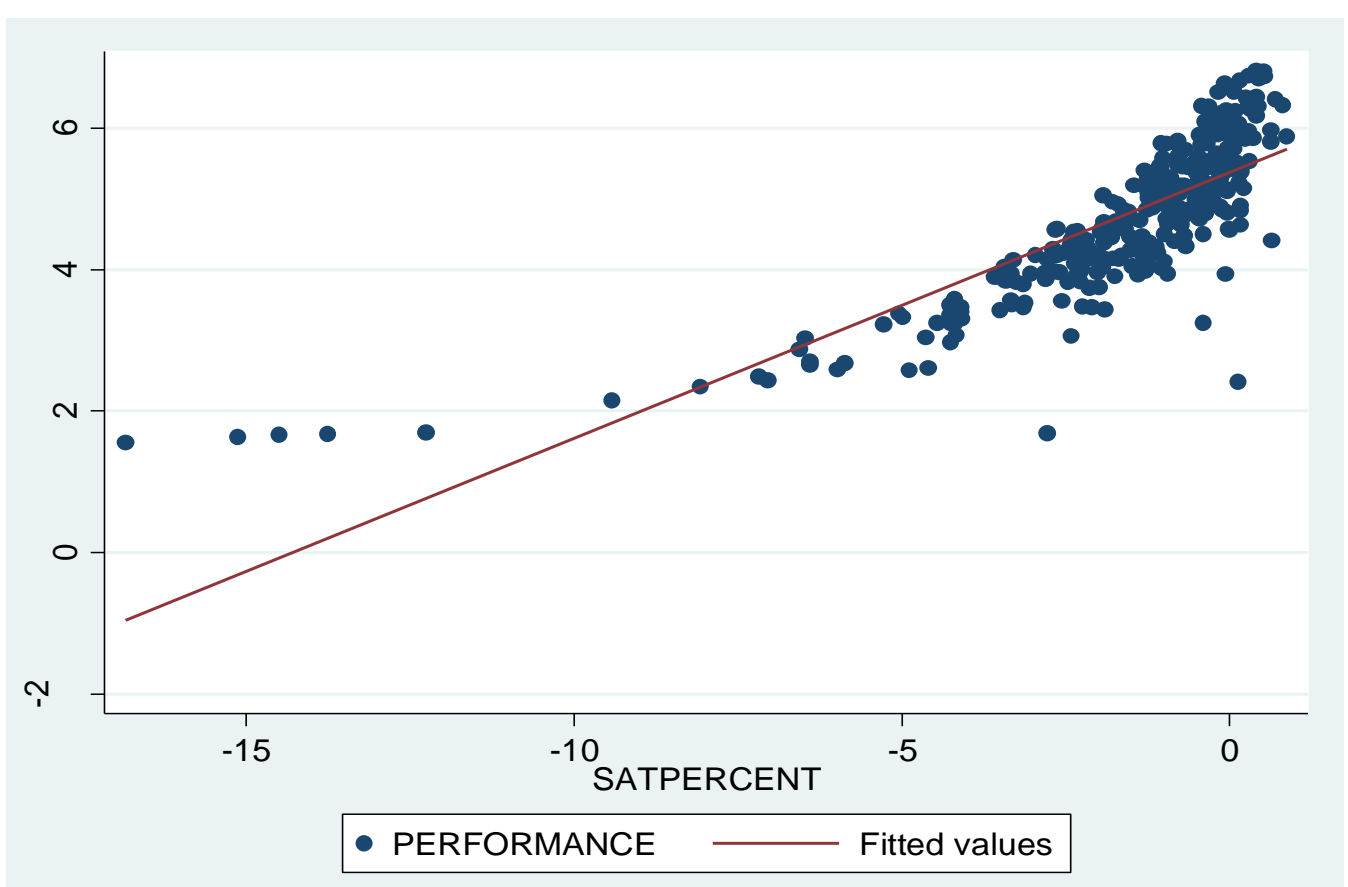

Figure 1. Satisfaction as a percentage to perception 
The items that are falling at the left on the $\mathrm{x}$-axis shows where perception on performance were low but the satisfaction-perception percentages were very low. Such items are noted by high negative scores in Table 1 . Marketing managers and service quality officers need to work to improve service quality performance.

The researchers developed a graphical relationship between perception and expectation to show if students' expectation has relationship with their perception on Private Universities' performance. Figure 2 below shows the relationship.

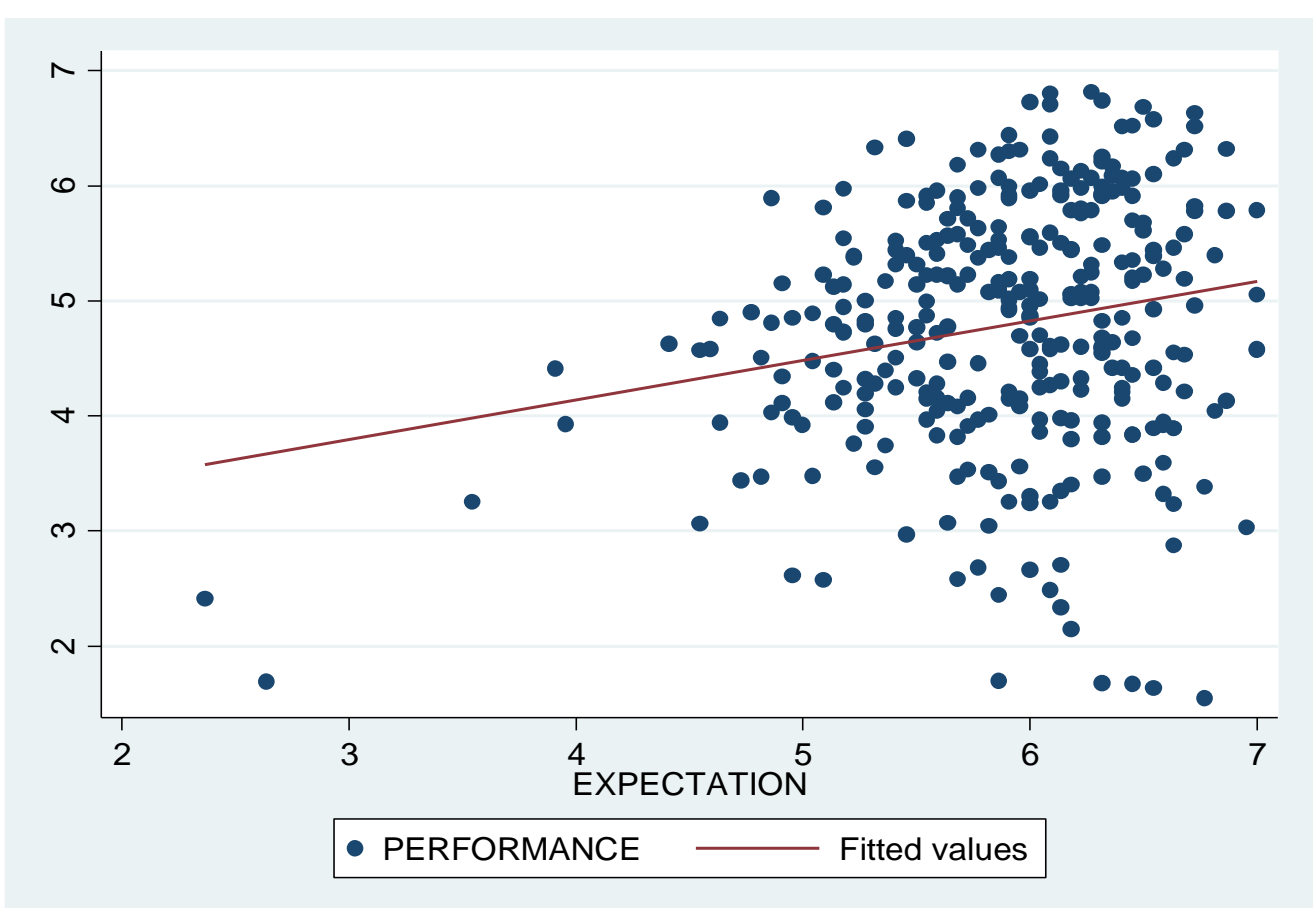

Figure 2. Relationship between students perception and expectation on private university service quality

The positive relationship between students' expectation and students' perception shows service quality improvement performance among Private Universities in the face of higher expectations by students. This may not be surprised as the nature of students attending Private Universities has the capacity to demand service quality improvements. In effect, customers' expectation has important role in service quality delivery and need to be recognised as such.

The cluster of scores at the extreme right shows that, students expect more on those items and the items above the line suggest a relative higher performance by Private Universities. In contrast, items that are below the line at the extreme right hand also shows items students' expectations are high but students' perception on performance by Private Universities are low. This graphical view makes more meaning to marketing strategic design and implementation.

The positive relationship between the satisfaction define as the gap quality and students' perception on performance, shows the extent to which perception improvement on performance can increase satisfaction. All the items that are located above the zero ( 0 ) line on the y-axis shows where perception on performance yield real satisfaction. Below the zero $(0)$ on the same axis indicates dissatisfaction in the progressive performance. 


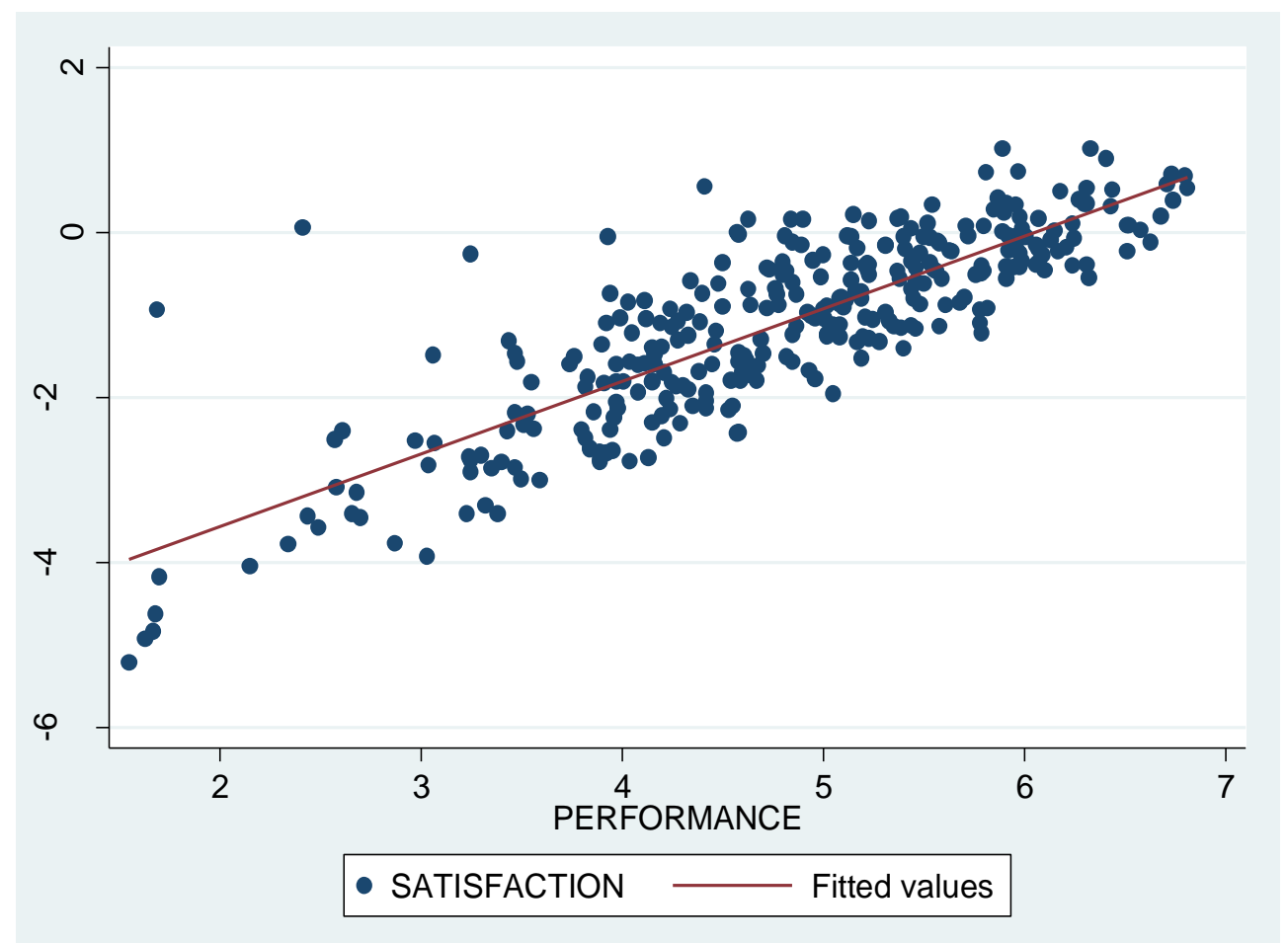

Figure 3. Satisfaction and perception

A critical analysis of the mean scores of items on perception, expectation and satisfaction shows that, in most instances where expectations are high perception on performance are equally high and satisfaction is better and vice versa (see Appendix 1). This causal effect can be linked to expectation pushing for higher service quality delivery and the outcome being improved satisfaction. Therefore, expectation cannot be completely left out of the service quality delivery equation as being advocated by performance-base theorist.

\subsection{Analysis of Perception, Expectation and Loyalty Using Structural Equation Model}

The study used structural equation model to show the effects of perception and expectation on students' loyalty. Indeed, there is positive of perception and expectation on loyalty. Figure 4 below shows the relationship. 


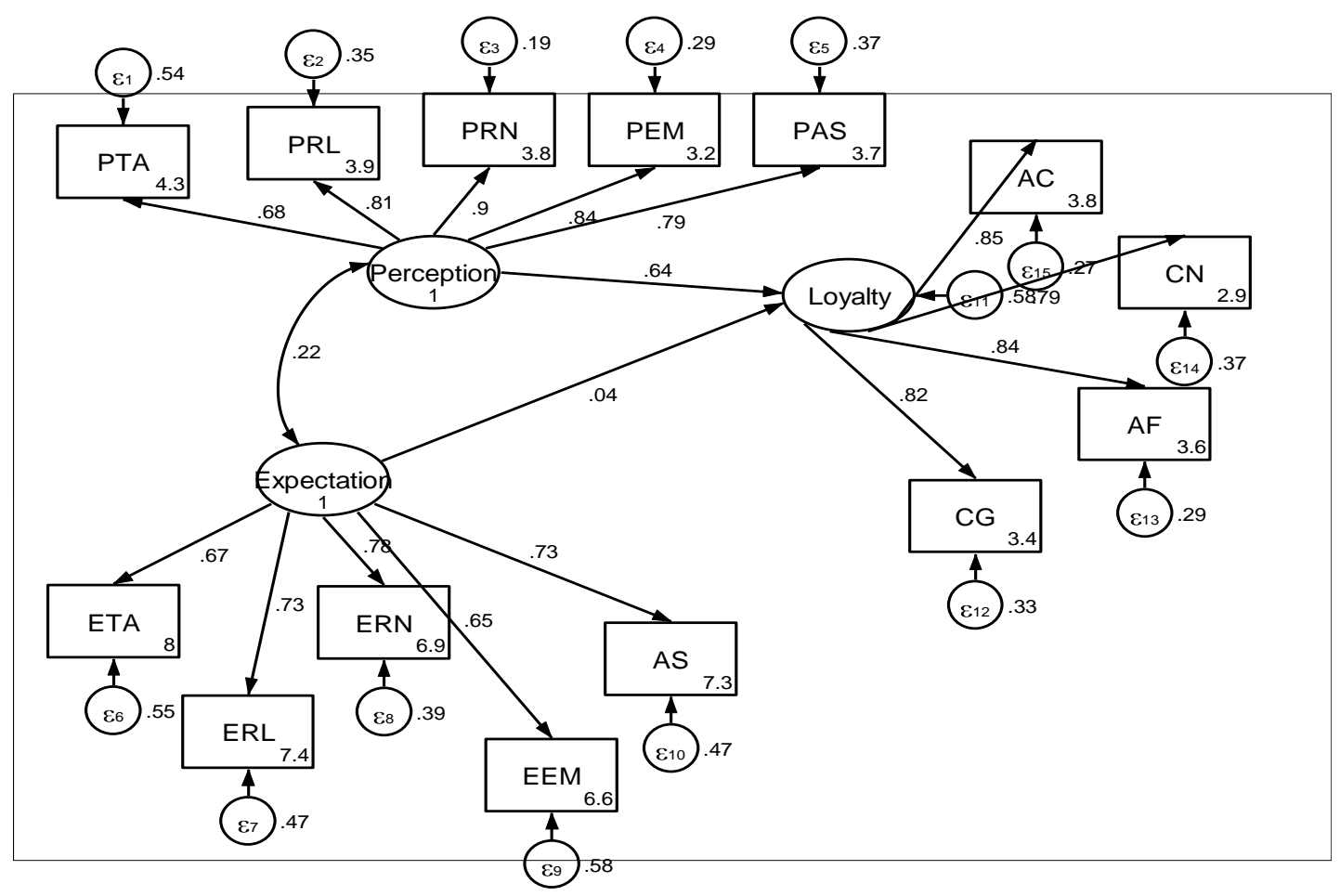

Figure 4. Structural relationship for perception, expectation and loyalty

The model has good loading for all the latent variables indicating their good measure of the variables involved (Hair et al). However, the loadings on tangibility on both perception and expectation are not much. Perhaps, it can be attributed to advances in technology which reduce the effect on the importance of tangible things.

From the model, perception on University's performance predicts students' loyalty better than students' expectation. This means that, the high expectations of students do not predict much to their loyalty and Private Universities needs to do more on expectation management. However, perception on performance predicts higher students' loyalty. The above model has relative good features to be considered as fit for use. The $\mathrm{Chi}^{2}$ value is 0.00 which significant and not good but the number of observation to number of variables ratio of 7:1 makes if good. The RMSEA value of 0.087 is fairly good, CFI value of 0.93 is good, TLI value of 0.92 is better, and SRMR value of 0.05 is good (see appendix 2).

The analysis of Satisfaction and Loyalty Latent variables shows a positive relation. The variables loaded well on the constructs meaning that, they actually measure Satisfaction and Loyalty. 


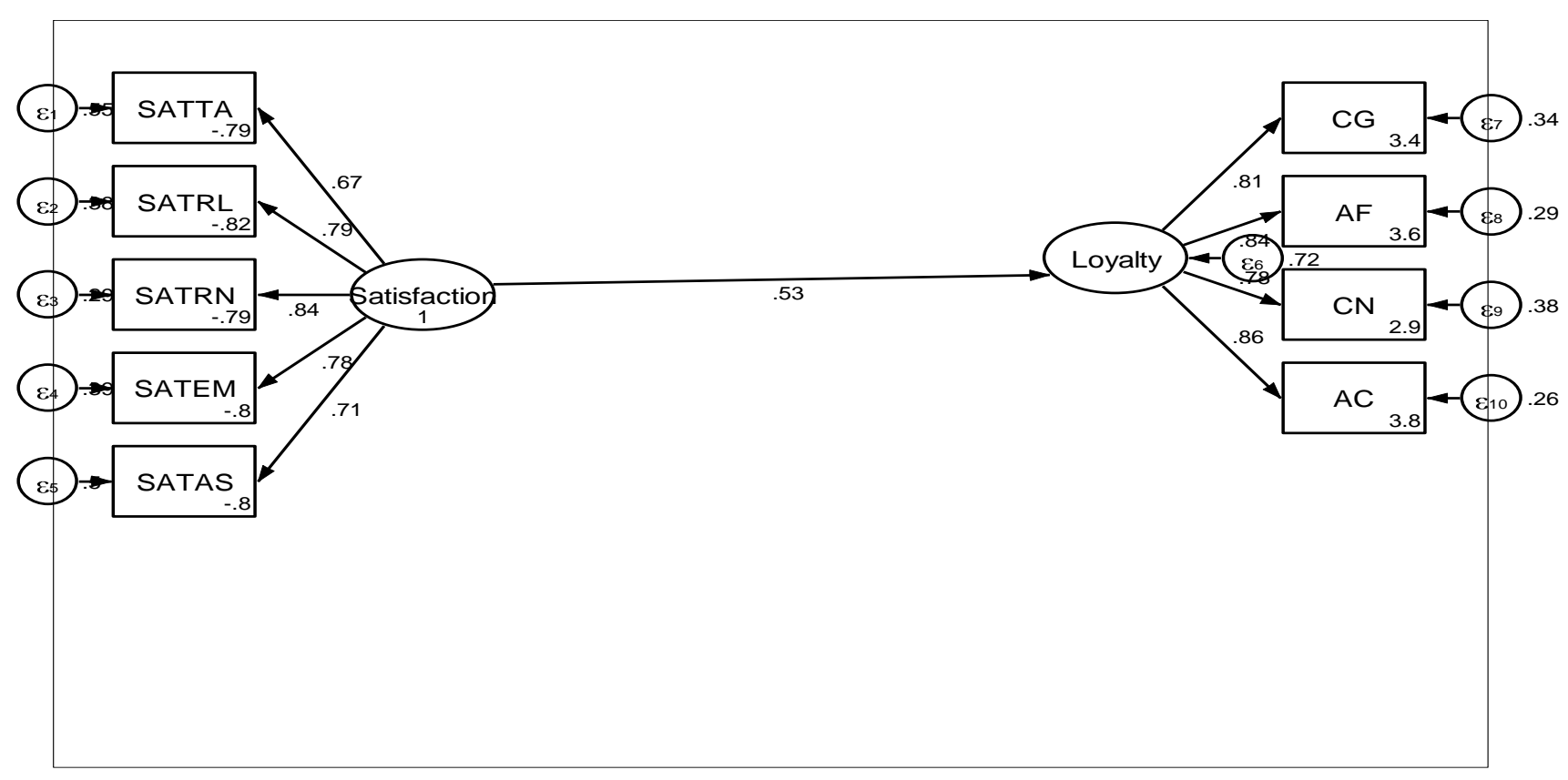

Figure 5. Analysis of satisfaction and loyalty using structural equation mode

The $\mathrm{Chi}^{2}$ value is 0.00 which significant and not good but the number of observation to number of variables ratio of 7:1 makes if good. The RMSEA value of 0.107 is not good, CFI value of 0.943 is good, TLI value of 0.921 is better, and SRMR value of 0.056 is fairly good (see Appendix 3). This shows a mix model fit.

\section{Conclusions and Managerial Implications}

The major conclusion from this research is that, there is some merit in using SERVQUAL method to measure service quality. However, the difference scores-base approach to determine satisfaction fails to give good model fit. These findings further support performance-base theorist's argument that the use of difference score to obtain a measure of satisfaction is not adequate (Cronin and Taylor, 1988; Teas, 1993).

The graphical display of perception and expectation provides more informative for marketing strategy design and implementation than to rely on the difference score as advocated by Parasuraman et al, (1985 and 1988). The use of satisfaction as a percentage to perception on performance reveals specific areas of service quality that requires marketing actions. The worse the percentage the more marketing action to improve service quality is required.

The authors have noted the widely use of SERVQUAL method in evaluating service quality across service sectors. In addition to it's widely usage, different authors have adopted varied ways to improve discussions and use of SERVQUAL method. Galeeva (2016) has argued that ratios describe the perceived service quality performance in a more reasonable and logical way for management use. Oliver (1980 cited in Galeeva, 2016) has indicated that it is good to treat customer satisfaction and perceived service quality as ratios instead of difference scores. Tufte (2001) has also emphasised that graphics reveal data more precise than statistical calculations.

The approach used has added to the different ways of using SERVQUAL method by researchers and marketing professional. What is still important is that, performance-base approach provides more empirical support to service quality assessment. However, the integration of expectation in the evaluation of service quality enhances marketing strategy design and implementation.

\section{Further Research}

The authors acknowledge the limitations on the use of SERVQUAL method to evaluate service quality. Hence, it is recommended that SERVPERF and HEdPERF should also be used in future research. Other graphical approaches should also be explored the improve SERVQUAL method because many researchers and marketing professionals are using it. 


\section{References}

Abdullah, F. (2005). The development of HEdPERF: A new measuring instrument of service quality for higher education. International Journal of Consumer Studies.

Abdullah, F. (2006). Measuring service quality in higher education: HEdPERF vwesus SERVPERF. Marketing Intelligence \& Planning, 24(1), 31-47. https://doi.org/10.1108/02634500610641543

Abdullah, F. (2006). The development of HEdPERF: a new measuring instrument of service quality for the higher education sector. International Journal of Customer Studies, 30(6), 569-581. https://doi.org/10.1111/j.1470-6431.2005.00480.x

Babakus, E., \& Boiler, G.W. (1992). An empirical assessment of the SERVQUAL scale. Journal of Business Research, 24, 253-268. https://doi.org/10.1016/0148-2963(92)90022-4

Bobalca, C., Gatej, C., \& Ciobanu, O. (2012). Developing a scale to measure customer loyalty. Procedia Economics and Finance, 3, 623-628. https://doi.org/10.1016/S2212-5671(12)00205-5

Cronin, J., \& Taylor, S. (1994). SERVPERF versus SERVQUAL: Reconciling performance-based and perception-minus-expectations measurement of service quality. Journal of Marketing, 58(1), 125-131. https://doi.org/10.2307/1252256

Cronin, J.J., \& Taylor, S.A. (1992). Measuring service quality: A re-examination and extension. Journal of Marketing, 56, 55-68. https://doi.org/10.2307/1252296

Fadeeva, N. (2012). Service quality assessment methodology. TGTU Vestnik, 18(2).

Galeeva, R. (2010). Marketing research of the university sector of educational services' market in the region: Part 2: Students' ratio of higher education and their perception of the universities educational services quality. Marketing, 114(5), 116-127.

Gronroos, C. (1990). Service Management and Marketing: Managing the Moments of Truth in Service Competition. Lexington, MA: Lexington Books.

Hair, J.F., Anderson, R.E., Tatham, R.L., \& Black, W.C. (1995). Multivariate Data Analysis with Readings. Prentice-Hall, Englewood Cliff, NJ.

Hammasi, M., Strong, K., \& Taylor, S. (1994). Measuring service quality for strategic planning and analysis in service firms. Journal of Applied Business Research, 10(4), 24-34.

Jiang, H., \& Zhang, Y. (2016). An investigation of service quality, customer satisfaction and loyalty in China's airline market. Journal of air transport management, $57, \quad 80-88$. https://doi.org/10.1016/j.jairtraman.2016.07.008

Kang, G., \& James, J. (2004). Service quality dimensions: An examination of Gronroos's service quality model. Managing Service Quality, 14(4), 226-277. https://doi.org/10.1108/09604520410546806

Krejcie, R., \& Morgan, D. (1970). Determining sample size for research activities. Educational and Psychological Measurement, 30, 607-610. https://doi.org/10.1177/001316447003000308

Lee, H, Lee, Y., \& Yoo, D. (2000). The determinants of perceived service quality and its relationship with satisfaction. Journal of Services Marketing, 14(3), 217-231. https://doi.org/10.1108/08876040010327220

Novatorov, E. (2000). Conceptual and methodological bases of quality's marketing research in the area of service. Marketing and Marketing Research in Russia, 29(5), 4-13.

Ojo, T.K., Mireku, D.O., Dauda, S., \& Nutsogbodo, R.Y. (2014). Service quality and customer satisfaction of public transport on Cape Coast-Accra route, Ghana. Developing Country Studies, 4(18).

Oliver, R.L. (1980, November). Cognitive model of the antecedents and consequences of satisfaction decision. Journal of Marketing Research, 17, 460-469. https://doi.org/10.2307/3150499

Oliver, R.L. (1999). Whence consumer loyalty?. Journal of Marketing, 63, 33-44. https://doi.org/10.2307/1252099

Parasuraman, A., Zeithaml, V.A., \& Berry, L.L. (1988). SERVQUAL: Amultiple-item scale for measuring consumer perceptions of service quality. Journal of Retailing, 64(1), 12-40.

Parasuraman, A., Zeithaml, V.A., \& Berry, L.L. (1991). More on improving service quality measurement. Journal of Retailing, 69(1), 140-147. https://doi.org/10.1016/S0022-4359(05)80007-7 
Parasuraman, A., Zeithaml, V.A., \& Berry, L.L. (1991). Refinement and reassessment of the SERVQUAL scale. Journal of Retailing, 67, 420-450.

Parasuraman, A., Zeithaml, V.A., \& Berry, L.L. (1994). Reassessment of expectations as a comparison standard in measuring service quality: implications for future research. Journal of Marketing, 58, 111-124. https://doi.org/10.2307/1252255

Pepra, A.A., \& Atara, B.A. (2014). Assessing patient's satisfaction using SERVQUAL model: Acase of Sunyani Regional Hospital Ghan. International Journal of Business and Social Research, 4(2), 133-143.

Teas, R.K. (1993). Expectations, performance evaluation, and consumers' perceptions of quality. Journal of Marketing, 57(4), 18-34. https://doi.org/10.2307/1252216

Teas, R.K. (1994). Consumer expectations and the measurement of perceived service quality. Journal of Professional services Marketing, 8(2), 33-54. https://doi.org/10.1300/J090v08n02_05

Turkson, P.K. (2008/2009). Client satisfaction survey of healthcare delivery in rural Ghana using service quality measurement (SERVQUAL) approach. Ghana Social Science Journal, 5 \& 6(1 \& 2), 217-235.

Young, C., Cunningham, L., \& Lee, M. (1994). Assessing service quality as an effective management tool: The case of the airline industry. Journal of Marketing, 2(2), 76-96. https://doi.org/10.1080/10696679.1994.11501652

Yunus, N.S.N.M., Bojei, J., \& Rashid, W.E.W. (2013). Service quality towards customer loyalty in Malaysia's domestic low cost airline services. International Journal of e-Education, e-Business, e-Management and e-Learning, 3(4), 333-336.

Zeithaml, V.A., \& Bitner, M.J. (1996), Service Marketing. McGraw-Hill, Singapore.

\section{Christian Service University College \\ School of Business \\ Service Quality and Loyalty Survey}

This is a survey in service quality measurement and loyalty for students in Private Universities in Ghana. I would be most grateful if you could serve as a respondent to this questionnaire. Kindly circle the number that truly reflects your opinion on the scale from 1 (strongly disagree) to 7 (strongly agree). There is no right or wrong answer, all that the researchers are interested in is your opinion. Thank you in advance.

\section{Expectation Scale}

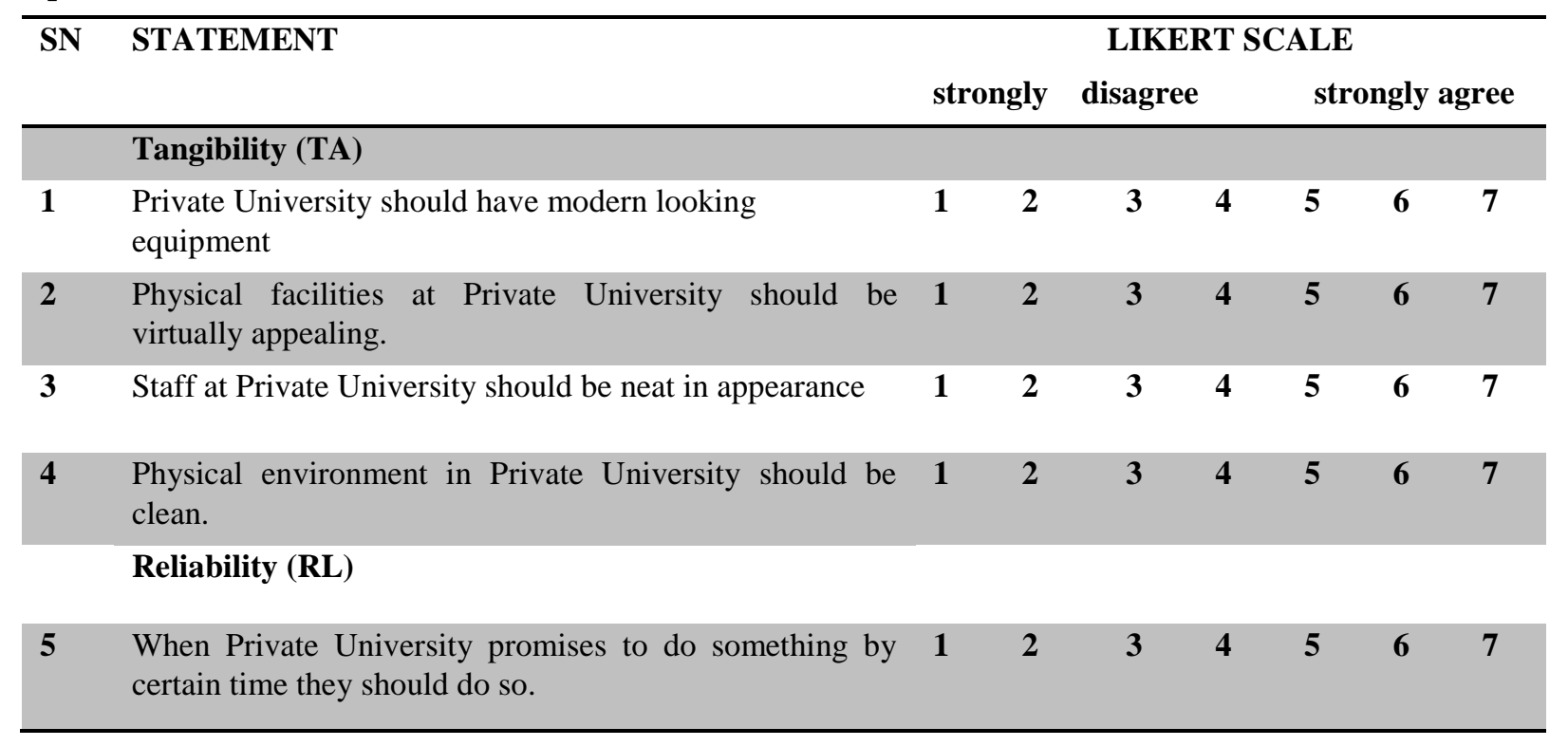




\begin{tabular}{|c|c|c|c|c|c|c|c|c|}
\hline 6 & Private University should get things right the first time. & 1 & 2 & 3 & 4 & 5 & 6 & 7 \\
\hline 7 & $\begin{array}{l}\text { Private University should provide its services at the time } \\
\text { it promises to do so. }\end{array}$ & 1 & 2 & 3 & 4 & 5 & 6 & 7 \\
\hline 8 & Private University should insist on error-free records. & 1 & 2 & 3 & 4 & 5 & 6 & 7 \\
\hline \multirow[t]{3}{*}{9.} & Staff at Private University should show sincere & 1 & 2 & 3 & 4 & 5 & 6 & 7 \\
\hline & Interest to solve students' problems & & & & & & & \\
\hline & Responsiveness (RN) & & & & & & & \\
\hline 10 & $\begin{array}{l}\text { Staff at Private University should give prompt services to } \\
\text { students. }\end{array}$ & 1 & 2 & 3 & 4 & 5 & 6 & 7 \\
\hline 11 & $\begin{array}{l}\text { When I have a problem, staff at Private University should } \\
\text { show sincere interest in solving it. }\end{array}$ & 1 & 2 & 3 & 4 & 5 & 6 & 7 \\
\hline 12 & $\begin{array}{l}\text { Staff at Private University should always be willing to } \\
\text { help students. }\end{array}$ & 1 & 2 & 3 & 4 & 5 & 6 & 7 \\
\hline \multirow[t]{2}{*}{13} & $\begin{array}{l}\text { Staff at Private University should make information } \\
\text { easily obtainable by students }\end{array}$ & 1 & 2 & 3 & 4 & 5 & 6 & 7 \\
\hline & Empathy (EM) & & & & & & & \\
\hline 14 & $\begin{array}{l}\text { Private University should give students individual } \\
\text { attention. }\end{array}$ & 1 & 2 & 3 & 4 & 5 & 6 & 7 \\
\hline 15 & $\begin{array}{l}\text { Private University should have staffs who give students } \\
\text { personal attention. }\end{array}$ & 1 & 2 & 3 & 4 & 5 & 6 & 7 \\
\hline 16 & $\begin{array}{l}\text { Private University should have students' best interest at } \\
\text { heart. }\end{array}$ & 1 & 2 & 3 & 4 & 5 & 6 & 7 \\
\hline 17 & $\begin{array}{l}\text { The staff of Private University should understand the } \\
\text { specific needs of its students. }\end{array}$ & 1 & 2 & 3 & 4 & 5 & 6 & 7 \\
\hline \multirow[t]{2}{*}{18} & $\begin{array}{l}\text { My University has operating hours convenient to all } \\
\text { students. }\end{array}$ & 1 & 2 & 3 & 4 & 5 & 6 & 7 \\
\hline & Assurance (AS) & & & & & & & \\
\hline 19 & $\begin{array}{l}\text { Staff at Private University should have the knowledge to } \\
\text { answer students' question. }\end{array}$ & & & & & & & \\
\hline 20 & $\begin{array}{l}\text { The behaviour of staff at Private University should instill } \\
\text { confidence in students. }\end{array}$ & & & & & & & \\
\hline 21 & $\begin{array}{l}\text { Students should feel safe in dealing with Private } \\
\text { University. }\end{array}$ & & & & & & & \\
\hline 22 & $\begin{array}{l}\text { Staff at Private University should be consistently } \\
\text { courteous with students. }\end{array}$ & & & & & & & \\
\hline
\end{tabular}




\section{Perceptions Scale}

\begin{tabular}{|c|c|c|c|c|c|c|c|c|}
\hline \multirow[t]{2}{*}{ SN } & \multirow[t]{2}{*}{ STATEMENT } & \multicolumn{7}{|c|}{ LIKERT SCALE } \\
\hline & & \multicolumn{2}{|c|}{ strongly } & \multicolumn{2}{|c|}{ disagree } & \multicolumn{3}{|c|}{ strongly agree } \\
\hline & & & & & & & & \\
\hline 1 & My university has modern looking equipments. & 1 & 2 & 3 & 4 & 5 & 6 & 7 \\
\hline 2 & $\begin{array}{l}\text { The physical facilities in my University are virtually } \\
\text { appealing. }\end{array}$ & 1 & 2 & 3 & 4 & 5 & 6 & 7 \\
\hline 3 & Lecturers in my University are neat in appearance. & $\mathbf{1}$ & 2 & 3 & 4 & 5 & 6 & 7 \\
\hline \multirow[t]{2}{*}{4} & The physical environment of my University is clean. & 1 & 2 & 3 & 4 & 5 & 6 & 7 \\
\hline & Reliability (RL) & & & & & & & \\
\hline 5 & $\begin{array}{l}\text { When my University promises to do something by certain } \\
\text { time it does so. }\end{array}$ & 1 & 2 & 3 & 4 & 5 & 6 & 7 \\
\hline 6 & My University gets things done right the first time. & 1 & 2 & 3 & 4 & 5 & 6 & 7 \\
\hline 7 & $\begin{array}{l}\text { My University provides its services at the time it } \\
\text { promises to do so. }\end{array}$ & 1 & 2 & 3 & 4 & 5 & 6 & 7 \\
\hline 8 & My University insists on error-free records. & 1 & 2 & 3 & 4 & 5 & 6 & 7 \\
\hline \multirow[t]{2}{*}{9.} & $\begin{array}{l}\text { Staff in my University shows sincere } \\
\text { interest to solve my problems }\end{array}$ & 1 & 2 & 3 & 4 & 5 & 6 & 7 \\
\hline & Responsiveness (RN) & & & & & & & \\
\hline 10 & Staff in my University gives me prompt services. & 1 & 2 & 3 & 4 & 5 & 6 & 7 \\
\hline 11 & $\begin{array}{l}\text { When I have a problem, my University shows sincere } \\
\text { interest in solving it. }\end{array}$ & 1 & 2 & 3 & 4 & 5 & 6 & 7 \\
\hline 12 & Staffs in my University are willing to help me. & 1 & 2 & 3 & 4 & 5 & 6 & 7 \\
\hline \multirow[t]{2}{*}{13} & $\begin{array}{l}\text { Staff in my University make information easily } \\
\text { Obtainable to students. }\end{array}$ & $\mathbf{1}$ & 2 & 3 & 4 & 5 & 6 & 7 \\
\hline & Empathy (EM) & & & & & & & \\
\hline 14 & My University gives me individual attention. & 1 & 2 & 3 & 4 & 5 & 6 & 7 \\
\hline 15 & My University has staffs who give me personal attention. & 1 & 2 & 3 & 4 & 5 & 6 & 7 \\
\hline 16 & My University has my best interest at heart. & 1 & 2 & 3 & 4 & 5 & 6 & 7 \\
\hline 17 & $\begin{array}{l}\text { The staffs of my University understand my specific } \\
\text { needs. }\end{array}$ & 1 & 2 & 3 & 4 & 5 & 6 & 7 \\
\hline \multirow[t]{2}{*}{18} & $\begin{array}{l}\text { My University has operating hours convenient to all } \\
\text { students. }\end{array}$ & 1 & 2 & 3 & 4 & 5 & 6 & 7 \\
\hline & Assurance (AS) & & & & & & & \\
\hline 19 & $\begin{array}{l}\text { The staffs in my University tell me when services are } \\
\text { performed. }\end{array}$ & 1 & 2 & 3 & 4 & 5 & 6 & 7 \\
\hline 20 & $\begin{array}{l}\text { Staffs in my University are never too busy to respond to } \\
\text { my request. }\end{array}$ & 1 & 2 & 3 & 4 & 5 & 6 & 7 \\
\hline 21 & $\begin{array}{l}\text { Staffs in my University are consistently courteous with } \\
\text { me. }\end{array}$ & 1 & 2 & 3 & 4 & 5 & 6 & 7 \\
\hline 22 & $\begin{array}{l}\text { The behaviour of staff in my University instills } \\
\text { confidence in me. }\end{array}$ & 1 & 2 & 3 & 4 & 5 & 6 & 7 \\
\hline
\end{tabular}




\section{Loyalty Scale}

\begin{tabular}{|c|c|c|c|c|c|c|c|c|}
\hline \multirow[t]{2}{*}{$\mathbf{S N}$} & \multirow[t]{2}{*}{ STATEMENT } & \multicolumn{7}{|c|}{ LIKERT SCALE } \\
\hline & & \multicolumn{2}{|c|}{ strongly } & \multicolumn{2}{|c|}{ disloyal } & \multicolumn{3}{|c|}{ strongly loyal } \\
\hline 1 & I prefer to use the services of this University & 1 & 2 & 3 & 4 & 5 & 6 & 7 \\
\hline 2 & I think this University has the best services at present & 1 & 2 & 3 & 4 & 5 & 6 & 7 \\
\hline \multirow[t]{2}{*}{3} & $\begin{array}{l}\text { I prefer to be part of this University brand instead of } \\
\text { others }\end{array}$ & 1 & 2 & 3 & 4 & 5 & 6 & 7 \\
\hline & Affective (AF) & & & & & & & \\
\hline 4 & I attended this University because I really like it & 1 & 2 & 3 & 4 & 5 & 6 & 7 \\
\hline 5 & I am pleased to attend this University instead of others & 1 & 2 & 3 & 4 & 5 & 6 & 7 \\
\hline 6 & I like this University brand more than other brands & 1 & 2 & 3 & 4 & 5 & 6 & 7 \\
\hline 7 & $\begin{array}{l}\text { I feel more attached to this University brand than to other } \\
\text { brands }\end{array}$ & 1 & 2 & 3 & 4 & 5 & 6 & 7 \\
\hline \multirow[t]{2}{*}{8} & $\begin{array}{l}\text { I am more interested in this University brand than other } \\
\text { brands }\end{array}$ & 1 & 2 & 3 & 4 & 5 & 6 & 7 \\
\hline & Conative $(\mathrm{CN})$ & & & & & & & \\
\hline 9 & $\begin{array}{l}\text { I intend to pursue further studies at this University in the } \\
\text { future }\end{array}$ & 1 & 2 & 3 & 4 & 5 & 6 & 7 \\
\hline \multirow[t]{2}{*}{10} & $\begin{array}{l}\text { I intend to buy other educational services from this } \\
\text { University }\end{array}$ & 1 & 2 & 3 & 4 & 5 & 6 & 7 \\
\hline & Action (AC) & & & & & & & \\
\hline 11 & I recommend this University those who ask my advice & 1 & 2 & 3 & 4 & 5 & 6 & 7 \\
\hline 12 & $\begin{array}{l}\text { I say positive things about this University to other } \\
\text { persons }\end{array}$ & 1 & 2 & 3 & 4 & 5 & 6 & 7 \\
\hline 13 & $\begin{array}{l}\text { I will consider this University as my first choice when I } \\
\text { want to seek for further education }\end{array}$ & 1 & 2 & 3 & 4 & 5 & 6 & 7 \\
\hline
\end{tabular}

\section{Demographic information}

1. Which University do you attend?
(a) Baptist University
(b) Christ Apostolic University
(c) Christian Service University
(d) University College of Management Studies
(e) Garden City University College

2. What is your programme of study?
(a) Business Studies
(b) Arts
(c) Theology
(d) Applied Science

3. Which session do you attend?
(a) Day
(b) Evening
(c) Weekend
(d) Sandwich

4. Which level/year are you in your studies?
(a) Level 100
(b) Level 200
(c)Level 300
(d)Level 400
(e)Postgraduate

5. What is your gender?
(a) Male
(b) Female 